\title{
Global Happiness: Continental and Cross-Cultural Models Perspective
}

\section{Dulababu T*}

Department of Economics, Alliance School of Business, Alliance University, Bengaluru, Karnataka, India

\begin{abstract}
Happiness is ultimate goal of human life. It is the outcome of factors such as high purchasing power, quality standard of living, and safety measures for life, profession and family and so on. This research probes whether the scores of happiness, provided by the World Happiness Reports, is same among the continents on average on one hand and whether the scores of happiness differ among the different cultural models based on the five dimensions proposed by Hofstede's on the other. Further the research suggests how best the countries of low happiness should strive for economic development and transform their cultures by adopting best practices to reach the highest global happiness.
\end{abstract}

Keywords: Happiness; Cross-culture; Power distance; Uncertainty avoidance; Culture diversity

\section{Introduction}

Happiness is a psychological state of condition. Happiness or wellbeing is not only a personal goal, but also society benefits from happier citizens. Happier people seem to be more productive and cooperative at work as well as more sociable and healthy $[1,2]$. Happiness is defined in four aspects:

- Free of physical sufferings, illnesses or disabilities;

- Being socially acceptable, getting along well with other people, being respected and cared for, not being isolated;

- Free of worries and hardships, being able to live a carefree and joyful life; and

- Possessing a healthy, normal mind, being accepted by the society [3].

Similarly as per the World Happiness Report of 2017 the six factors are GDP per capita, healthy years of life expectancy, social support (as measured by having someone to count on in times of trouble), trust (as measured by a perceived absence of corruption in government and business), perceived freedom to make life decisions, and generosity (as measured by recent donations) are the major factors to determine the state of happiness. As per the report the top 10 countries whose score is high on these dimensions are in possession of more degree of happiness.

\section{Review of Literature}

Culture may affect happiness or State of Well-being (SWB) in terms of the amount, extent, or degree of happiness. Thus, culture "can influence mean levels of SWB" [4].

Suh [5] describes that in individualist cultures, people have stronger self-identity consistency and consistent self-view implying that they have crystal clear self-knowledge, and hence they have less affected self-experiences leading to greater happiness.

Lu et al. [6] have disclosed that the East-Asians are socially oriented and the Euro-Americans are individually oriented.

Culture of individual oriented prevails in Western countries that are Europe and America. People give importance to individual freedom, individual achievement and etc. Thus, the relationships between happiness and individual effort and achievement are more direct, positive making higher levels of happiness. In the collectivist or team oriented cultures like Japan, Korea, and China, people put more importance on human relationships, including families, colleagues and neighbors. In these cultures, happiness is affected by the evaluation of others.

However, past research reveals that cultures with maximum collectivism, such as, East Asian regions are more likely to promote social engagement on one hand and socially engaged experiences of happiness on the other hand [3,7-10].

Arrindell et al. [11] in his research finds a negative relationship between PDI (Power Distance Index) and State of Well Being that is happiness. More the degree of power distance more will be the inequalities not only in work organizations but also in areas such as social status and prestige, wealth and civil rights. Thus a significantly negative association is predicted between PDI and national levels of happiness or SWB.

Chui and Kwok [12] through his research disclosed that uncertainty avoidance index (UAI) mainly refers to the extent to which individuals expect orderliness, consistent structured lifestyles, a clear specification of social expectations, and rules and laws to cover unpredictable/ harmful/loss incurring situations [13]. Therefore, a high UAI may not necessary lead to stress and nervousness [14].

In Hofstede's view also, societies with high UAI scores are symbolized by tension, lower hope or desire as for as individual advancement concerned, and negativity about work-related issues. Using Hofstede's culture UAI data, Arrindell et al. [11] found that UAI is negatively related to happiness.

\section{Statement of Problem}

The following are the research gaps are identified based on the review of literature:

*Corresponding author: Dulababu T, Department of Economics, Alliance Schoo of Business, Alliance University, Bengaluru, Karnataka, India, Tel: +08030938100; E-mail: tapaldulababu@gmail.com

Received October 25, 2017; Accepted November 06, 2017; Published November 13, 2017

Citation: Dulababu T (2017) Global Happiness: Continental and Cross-Cultural Models Perspective. J Glob Econ 5: 268. doi: 10.4172/2375-4389.1000268

Copyright: @ 2017 Dulababu T. This is an open-access article distributed under the terms of the Creative Commons Attribution License, which permits unrestricted use, distribution, and reproduction in any medium, provided the original author and source are credited. 
This paper probes the degree of happiness changes in continental and dfifferent cross-cuflturafl modefls perspectfive.

\section{Objectives of the Study}

The following are the objectives of the research paper:

- To study the scores of happiness revealed by the World Happiness Report from 2010-12 to 2014-16.

- To study global happiness among the continents.

- To study global happiness with respect to different cultural models propounded by Hofstede's.

\section{Research design}

The research frame-work of the research paper is as follows:

\section{Data type, source, collection and period}

Basically the secondary data are the base for the research work. The major source of the data are "World Happiness Report (WHR)". Scores of happiness is given nation-wise in the scale of 1 to 10 (where $1=$ low, and $10=$ high). The scores of happiness are collected nation-wise for three year period.

\section{Period of the data}

The data are collected for the period, namely $2010-12,2012-14$ and 2014-16 from the WHR 2012, 2014 and 2016.

\section{Data classification and tabulation}

- The scores of happiness nation wise (collected data) is classified based on:

- Continents such as Africa, Asia, Australia, Europe, North America and South America that is grouping the nations under each continent

- Hofstede's cultural models such as; Individual vs. Team Oriented, High Power Distance Vs. Low Power Distance, High Masculine Oriented vs. Non-Masculine Oriented, High Uncertainty Avoidance Index vs. Low Uncertainty Avoidance Index and long Term Orientation vs. Short Term Orientation.

\section{Research Hypotheses}

The following are the research null hypotheses to test to dig the hidden insights to prescribe effective policies and strategies:

- There is no significant difference in the mean scores of global happiness among the periods, namely 2010-12, 2012-14 and 2014-16.

- There is no significant difference in the mean scores of global happiness among the continents.

- There is no significant difference in the mean scores of happiness in Africa continent among the periods, namely 2010-12, 2012-14 and 2014-16.

- There is no significant difference in the mean scores of happiness in Asia continent among the periods, namely 201012, 2012-14 and 2014-16.

- There is no significant difference in the mean scores of happiness in Australia continent among the periods, namely 2010-12, 2012-14 and 2014-16.
- There is no significant difference in the mean scores of happiness in Europe continent among the periods, namely 2010-12, 2012-14 and 2014-16.

- There is no significant difference in the mean scores of happiness in North America continent among the periods, namely 2010-12, 2012-14 and 2014-16.

- There is no significant difference in the mean scores of happiness in South America continent among the periods, namely 2010-12, 2012-14 and 2014-16.

- There is no significant difference in the mean scores of happiness in Individual (IDV) oriented cultural countries among the periods, namely 2010-12, 2012-14 and 2014-16.

- There is no significant difference in the mean scores of happiness in Team oriented cultural countries among the periods, namely 2010-12, 2012-14 and 2014-16.

- There is no significant difference in the mean scores of happiness between Individual (IDV) and Team oriented cultural countries among the periods, namely 2010-12, 201214 and 2014-16.

- There is no significant difference in the mean scores of happiness in High Power Distance Index (HPDI) cultural countries between 2010-12 and 2014-16.

- There is no significant difference in the mean scores of happiness in Low Power Distance Index (LPDI) cultural countries among the periods, namely 2010-12, 2012-14 and 2014-16.

- There is no significant difference in the mean scores of happiness between High Power Distance and Low Power Distance Index cultural countries between 2010-12 and 2014-16.

- There is no significant difference in the mean scores of happiness in Masculine dominated cultural countries among the periods, namely 2010-12, 2012-14 and 2014-16.

- There is no significant difference in the mean scores of happiness in Feminine dominated cultural countries among the periods, namely $2010-12,2012-14$ and 2014-16.

- There is no significant difference in the mean scores of happiness between Masculine and Feminine dominated cultural countries between 2010-12 and 2014-16.

- There is no significant difference in the mean scores of happiness in High Uncertainty Avoidance Index cultural countries among the periods, namely 2010-12, 2012-14 and 2014-16.

- There is no significant difference in the mean scores of happiness in Low Uncertainty Avoidance Index cultural countries among the periods, namely 2010-12, 2012-14 and 2014-16.

- There is no significant difference in the mean scores of happiness between High and Low Uncertainty Avoidance Index cultural countries between 2010-12 and 2014-16

- There is no significant difference in the mean scores of happiness in Long Term Oriented cultural countries among the periods, namely $2010-12,2012-14$ and 2014-16.

- There is no significant difference in the mean scores of happiness in Short Term Oriented cultural countries among the periods, namely 2010-12, 2012-14 and 2014-16. 
- There is no significant difference in the mean scores of happiness between Long and Short Term Oriented cultural countries among 2010-12, 2012-14 and 2014-16.

\section{Statistical Tools}

The following mentioned statistical tools are used to analyze and test the hypotheses stated above:

- $\mathrm{t}$-Test to test the difference between two sample means given that the sizes of the two samples are less than 30 .

- Z-Test to test the difference between two sample means given that the sizes of the two samples are 30 or more

- ANOVA-single factor (one-way) to test the difference in mean value when samples are more than two such as to test the difference in mean scores among the three periods in a category like continent or a type of culture.

\section{Assumptions}

The following assumptions are made to carry out the research work:

- To analyze the scores of happiness of the countries in terms of cross-cultural dimensions, Hofstede's model and 5 dimensions are taken into consideration. The countries are grouped in each dimension by taking $50 \%$ of the top score into one group and the lower $50 \%$ scored countries into the other extreme group, for example, in the case of Power Distance the highest scored country was Malaysia with $104,50 \%$ of which 52 and scored countries are classified under High Power Distance Index (HPDI) cultured countries and less than 52 scored nations are grouped under Low Power Distance Index (LPDI) cultured countries. The same procedure is followed for the other dimensions.

- To analyze and test the listed hypotheses $5 \%$ level of significance is assumed and all the hypotheses are tested in 2 tailed.

\section{Limitations of the Study}

Hofstede's five cultural dimensions are taken to group the nations. But GLOBE research had developed and revealed more than five dimensions but the base was Hofstede's concept only. However, due to globalization and technology growth cultural convergence happening which could be a limiting factor of the research.

\section{Research Results}

The following are the results of the study.

\section{Global happiness scores}

As per Table 1, it is observed that global happiness scores are collected for 156 countries during 2010-12, 155 countries in 2012-14 and 149 countries in 2014-16. The global mean score of happiness is 5.419 (out of 10 point scale) in 2010-12 followed by 5.391 in 2012-14 and 5.373 in 2014-16. Further it is observed that the mean scores of global happiness are on declining trend in absolute terms.

\section{Continental mean scores of happiness}

Continental scores of happiness are also presented in Table 1. The countries of Asia, Africa and Europe constitute more than $85 \%$ of the world. The smallest continent is Australia consisting of only two countries namely, Australia and New Zealand. Australia is the toper continent having the highest mean score of happiness for the three periods with more than 7.2 out of 10 . Further both the countries of Australian continent have a very consistent score of happiness with not less than 7 points followed by South America followed by North America and Europe with a mean score of 6 plus points on an average. A little fluctuation is seen in these three continents. Asia with 45 nations in its cluster has a mean score of 5.3 points on an average. At the last Africa with 40 to 44 nations in its hold has a mean score of happiness of about 4.3 points. The mean score of happiness do differ significantly among the continents.

\begin{tabular}{|c|c|c|c|c|c|}
\hline S. No & Continents & Year & No. of Countries & Percentage & Mean Score of Happiness \\
\hline \multirow[t]{3}{*}{1} & \multirow[t]{3}{*}{ Africa } & $2010-2012$ & 44 & 28.2 & 4.441 \\
\hline & & $2012-2014$ & 43 & 27.7 & 4.300 \\
\hline & & $2014-2016$ & 40 & 26.8 & 4.226 \\
\hline \multirow[t]{3}{*}{2} & \multirow[t]{3}{*}{ Asia } & $2010-2012$ & 45 & 28.8 & 5.287 \\
\hline & & $2012-2014$ & 45 & 29.0 & 5.296 \\
\hline & & $2014-2016$ & 43 & 28.9 & 5.307 \\
\hline \multirow[t]{3}{*}{3} & \multirow[t]{3}{*}{ Australia } & $2010-2012$ & 2 & 1.3 & 7.286 \\
\hline & & $2012-2014$ & 2 & 1.3 & 7.285 \\
\hline & & $2014-2016$ & 2 & 1.3 & 7.299 \\
\hline \multirow[t]{3}{*}{4} & \multirow[t]{3}{*}{ Europe } & $2010-2012$ & 41 & 26.3 & 6.059 \\
\hline & & $2012-2014$ & 41 & 26.5 & 6.050 \\
\hline & & $2014-2016$ & 41 & 27.5 & 6.080 \\
\hline \multirow[t]{3}{*}{5} & \multirow[t]{3}{*}{ North America } & 2010-2012 & 13 & 8.3 & 6.128 \\
\hline & & $2012-2014$ & 13 & 8.4 & 6.146 \\
\hline & & $2014-2016$ & 13 & 8.7 & 6.034 \\
\hline \multirow[t]{3}{*}{6} & \multirow[t]{3}{*}{ South America } & $2010-2012$ & 11 & 7.1 & 6.305 \\
\hline & & $2012-2014$ & 11 & 7.1 & 6.349 \\
\hline & & $2014-2016$ & 10 & 6.7 & 6.099 \\
\hline \multirow[t]{3}{*}{7} & \multirow[t]{3}{*}{ Global } & $2010-2012$ & 156 & 100 & 5.419 \\
\hline & & $2012-2014$ & 155 & 100 & 5.391 \\
\hline & & $2014-2016$ & 149 & 100 & 5.373 \\
\hline
\end{tabular}

Table 1: Continent - mean scores of happiness - number of countries covered for the study. 
Further it is found that $45 \%$ of the nations covered by Australia, South America, North America and Europe are with a mean score of happiness greater than the mean score of happiness at the global level in the Table 1. The mean score of happiness of Asia is more or less same to the mean score of global happiness. But the mean score of happiness of Africa with 40 countries is lagging behind the mean score of global happiness. Besides, the mean score is on declining trend in Africa from 4.44 points to 4.22 pints (2010-12 to 2014-16). Asia, Australia and Europe are marginally on increasing trend in terms of mean score of happiness but North America and South America are declining trend in terms of mean score of happiness. The mean score do not differ significantly among the three time periods at global and overall level. Again to check the fluctuations in the mean scores of happiness of various continents test of hypotheses carried out at 5\% level of significance. It is revealed that in all the continents the mean score is same in all the three time periods.

\section{Cross-cultural models - mean scores}

Mean scores of happiness is analyzed based on the basis of Hofstede's five dimensional cultural models. A list of countries falling under the different dimensions are collected with their dimensional scores and arranged in the order of highest scores to the lowest and top $50 \%$ scoring countries are taken to high dimension like Individualistic Oriented (IDV), High Power Distance Index (HPDI), Masculine Dominated (MAS), High Uncertainty Avoidance Index (HUAI) and Long Term Oriented (LTO) cultures and the lower 50\% countries are grouped lower dimension such as Team Oriented (Team), Low Power Distance Index (LPDI), Feminine Dominated (Feminine), Low Uncertainty Avoidance Index (LUAI) and Short Term Oriented (STO) cultures as shown in Figure 1.

A maximum of 66 countries are classified by Hofstede's and the distribution of the countries under each dimension is presented in Table 2. It is observed that $33 \%$ of the countries fall under IDV and $67 \%$ fall under Team; 70\%, HPDI and 30\% LPDI; 56\% MAS and $44 \%$ Feminine; $62 \%$ HUAI and 38\% LUAI and $11 \%$ LTO and $27 \%$ STO.

It is observed that the countries with IDV culture do not differ significantly in terms of mean score of happiness during the three time periods. Similarly, with in Team oriented cultural countries the same observation is made. But between the two cultures namely, IDV and Team oriented, the mean score of happiness differ significantly (Table 3, hypotheses No. 9, 10 and 11).

Based on power distance, the countries with HPDI do not differ significantly in terms of mean score of happiness for the three time periods. Also there is no significant difference in mean score of happiness among the countries of LPDI culture for the three time periods. However there is significant difference in mean score of happiness between HPDI and LPDI cultural countries for the three time periods (Table 3, hypotheses No. 12, 13 and 14).

In the case of masculine dominated culture, the countries do not differ significantly in mean score of happiness during the three time periods. Similarly, in the case of feminine dominated countries, the mean of score of happiness is same for all the three time periods. Further, it is disclosed that there is no significant difference in the average score of happiness between masculine and feminine cultured countries for the three time periods (Table 3, hypotheses No. 15, 16, 17).

The countries falling under HUAI culture do have same mean score of happiness for the three time periods. The countries with LUAI culture also disclosed the same degree of happiness for the three time

\begin{tabular}{|c|c|c|c|c|}
\hline S. No & Cultural Model & Dimension & $\begin{array}{c}\text { No. of } \\
\text { countries }\end{array}$ & Percentage \\
\hline \multirow{2}{*}{1} & IDV VS Team & IDV & 22 & 33.3 \\
\cline { 3 - 5 } & & TEAM & 44 & 66.7 \\
\hline \multirow{2}{*}{2} & \multirow{2}{*}{ Power Distance } & HPDI & 46 & 69.7 \\
\cline { 3 - 5 } & & LPDI & 20 & 30.3 \\
\hline \multirow{2}{*}{3} & Masculine/Feminine & MASCULINE & 37 & 56.1 \\
\cline { 3 - 5 } & & FEMININE & 29 & 43.9 \\
\hline \multirow{2}{*}{4} & Uncertainty & HUAI & 41 & 62.1 \\
\cline { 3 - 5 } & Avoidance Index & LUAI & 25 & 37.9 \\
\hline \multirow{2}{*}{5} & Long/Short Term & LTO & 7 & 10.6 \\
\cline { 3 - 5 } & Orientation & STO & 18 & 27.3 \\
\hline & Total & & Max $=66$ & 100 \\
\hline
\end{tabular}

Note: Under LTO a very few countries are found from the website of Hofstede's.

Table 2: Number of countries under cultural models.

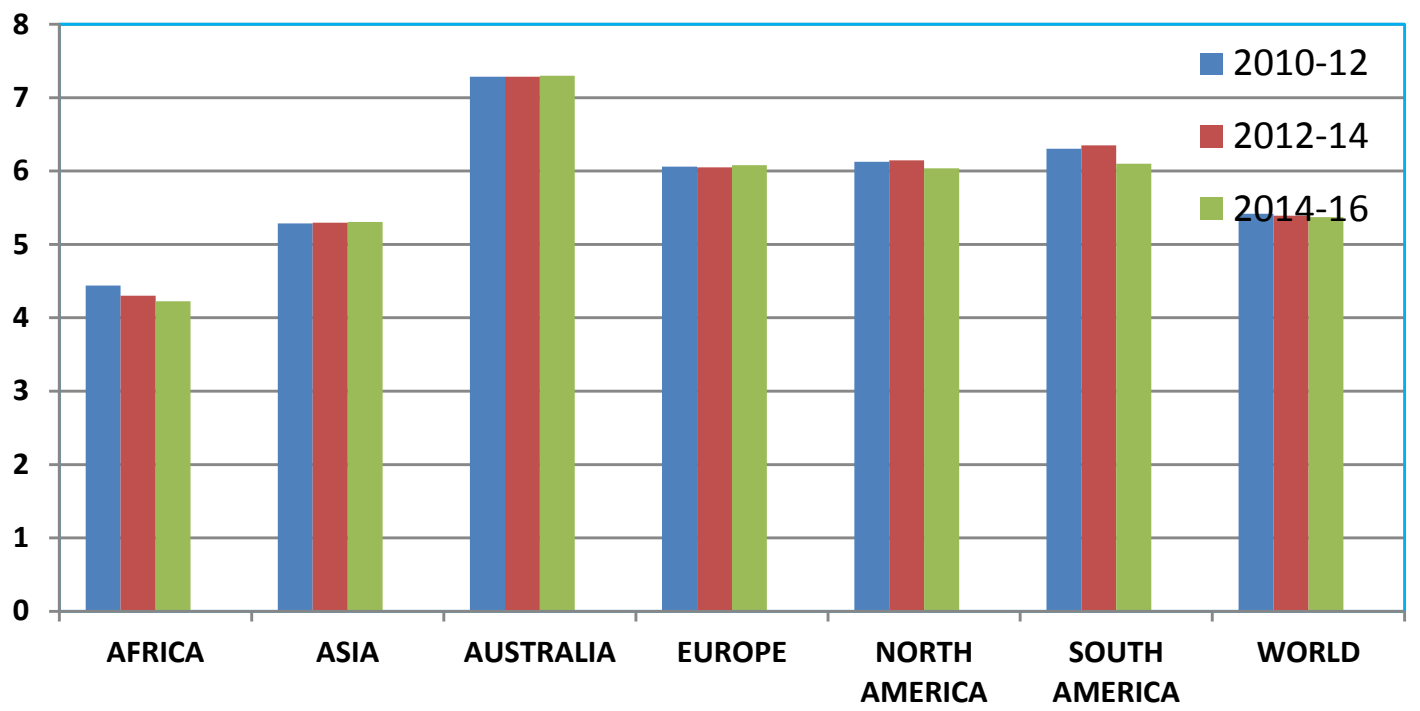

Figure 1: Continents mean Scores happiness. 
Citation: Dulababu T (2017) Global Happiness: Continental and Cross-Cultural Models Perspective. J Glob Econ 5: 268. doi: 10.4172/23754389.1000268

Page 5 of 7

\begin{tabular}{|c|c|c|c|c|c|}
\hline $\begin{array}{l}\text { Hypothesis } \\
\text { Number }\end{array}$ & Region/Culture & Period & Test Statistic & $\begin{array}{l}\text { Critical Value @ } 5 \% \text { Level of } \\
\text { Significance Given Sample Size }\end{array}$ & Decision \\
\hline 1 & $\begin{array}{l}\text { Mean Global Happiness Score among the three } \\
\text { periods }\end{array}$ & $2010-12,2012-14$ \& 2014-16 & $F=0.0856$ & 3.016, n1=156, n2=155, n3=149 & $\mathrm{H}_{0}$ is accepted \\
\hline 2 & Mean Global Happiness Score among the continents & $2010-12,2012-14 \& 2014-16$ & $F=532.72$ & $\begin{array}{l}5.064, n 1=44, n 2=45, n 3=2 \\
n 4=41, n 5=13, n 6=11\end{array}$ & $\mathrm{H}_{0}$ is rejected \\
\hline 3 & $\begin{array}{l}\text { Mean Global Happiness Score among the countries } \\
\text { in Africa for three periods }\end{array}$ & $2010-12,2012-14$ \& 2014-16 & $F=1.21$ & 3.07, n1=44,n2=43, n3=40 & $\mathrm{H}_{0}$ is accepted \\
\hline 4 & $\begin{array}{l}\text { Mean Global Happiness Score among the countries } \\
\text { in Asia for three periods }\end{array}$ & $2010-12,2012-14$ \& 2014-16 & $F=0.005$ & $3.065, \mathrm{n} 1=45, \mathrm{n} 2=45, \mathrm{n} 3=43$ & $\mathrm{H}_{0}$ is accepted \\
\hline 5 & $\begin{array}{l}\text { Mean Global Happiness Score among the countries } \\
\text { in Australia for three periods }\end{array}$ & $2010-12,2012-14$ \& 2014-16 & $F=0.043$ & $9.552, \mathrm{n} 1=\mathrm{n} 2=\mathrm{n} 3=2$ & $\mathrm{H}_{0}$ is accepted \\
\hline 6 & $\begin{array}{l}\text { Mean Global Happiness Score among the countries } \\
\text { in Europe for three periods }\end{array}$ & $2010-12,2012-14$ \& 2014-16 & $F=0.0102$ & $3.072, \mathrm{n} 1=\mathrm{n} 2=\mathrm{n} 3=41$ & $\mathrm{H}_{0}$ is accepted \\
\hline 7 & $\begin{array}{l}\text { Mean Global Happiness Score among the countries } \\
\text { in N. America for three periods }\end{array}$ & $2010-12,2012-14$ \& 2014-16 & $F=0.0465$ & $3.259, \mathrm{n} 1=\mathrm{n} 2=\mathrm{n} 3=13$ & $\mathrm{H}_{0}$ is accepted \\
\hline 8 & $\begin{array}{l}\text { Mean Global Happiness Score among the countries } \\
\text { in S. America for three periods }\end{array}$ & $2010-12,2012-14$ \& 2014-16 & $F=0.896$ & 3.328, n1=11, n2=11, n3=10 & $\mathrm{H}_{0}$ is accepted \\
\hline \multirow[t]{3}{*}{9} & \multirow{3}{*}{$\begin{array}{l}\text { Mean Global Happiness Score among the countries } \\
\text { of IDV culture for three periods }\end{array}$} & $2010-12 \& 2012-14$ & $t=0.227$ & $2.018, \mathrm{n} 1=22, \mathrm{n} 2=22$ & $\mathrm{H}_{0}$ is accepted \\
\hline & & $2012-14$ \& 2014-16 & $t=-0.103$ & $2.02, \mathrm{n} 2=22, \mathrm{n} 3=22$ & $\mathrm{H}_{0}$ is accepted \\
\hline & & $2014-16$ \& 2010-12 & $t=0.138$ & $2.020, n 3=22, n 1=22$ & $\mathrm{H}_{0}$ is accepted \\
\hline \multirow[t]{3}{*}{10} & \multirow{3}{*}{$\begin{array}{l}\text { Mean Global Happiness Score among the countries } \\
\text { of Team Culture for three periods }\end{array}$} & $2010-12$ \& 2012-14 & $z=0.08$ & $1.96, \mathrm{n} 1=44, \mathrm{n} 2=44$ & $\mathrm{H}_{0}$ is accepted \\
\hline & & $2012-14$ \& 2014-16 & $z=-0.496$ & $1.96, \mathrm{n} 2=44, \mathrm{n} 3=44$ & $\mathrm{H}_{0}$ is accepted \\
\hline & & $2014-16$ \& 2010-12 & $z=0.53$ & $1.96, n 3=44, n 1=44$ & $\mathrm{H}_{0}$ is accepted \\
\hline 11 & $\begin{array}{l}\text { Mean Global Happiness Score between IDV \& Team } \\
\text { cultured countries for three periods }\end{array}$ & $2010-12$ to $2014-16$ & $z=9.245$ & $1.96, \mathrm{n} 1=66, \mathrm{n} 2=132$ & $\mathrm{H}_{0}$ is rejected \\
\hline \multirow[t]{3}{*}{12} & \multirow{3}{*}{$\begin{array}{l}\text { Mean Global Happiness Score among the countries } \\
\text { of HPDI Culture for three periods }\end{array}$} & $2010-12$ \& 2012-14 & $z=0.071$ & $1.96, \mathrm{n} 1=46, \mathrm{n} 2=46$ & $\mathrm{H}_{0}$ is accepted \\
\hline & & $2012-14$ \& 2014-16 & $z=-0.394$ & $1.96, \mathrm{n} 2=\mathrm{n} 3=46$ & $\mathrm{H}_{0}$ is accepted \\
\hline & & 2014-16to 2010-12 & $z=0.469$ & $1.96, n 3=n 1=46$ & $\mathrm{H}_{0}$ is accepted \\
\hline \multirow[t]{3}{*}{13} & \multirow{3}{*}{$\begin{array}{l}\text { Mean Global Happiness Score among the countries } \\
\text { of LPDI Culture for three periods }\end{array}$} & $2010-12 \& 2012-14$ & $t=0.162$ & $2.02, n 1=n 2=20$ & $\mathrm{H}_{0}$ is accepted \\
\hline & & $2012-14$ \& 2014-16 & $t=0.027$ & $2.02, n 2=n 3=20$ & $\mathrm{H}_{0}$ is accepted \\
\hline & & 2014-16to 2010-12 & $\mathrm{t}=0.194$ & $2.02, n 3=n 1=20$ & $\mathrm{H}_{0}$ is accepted \\
\hline 14 & $\begin{array}{l}\text { Mean Global Happiness Score between HPDI \& } \\
\text { LPDI cultured countries for three periods }\end{array}$ & $2010-12$ to $2014-16$ & $z=8.747$ & $1.96, \mathrm{n} 1=60, \mathrm{n} 2=138$ & $\mathrm{H}_{0}$ is rejected \\
\hline \multirow[t]{3}{*}{15} & \multirow{3}{*}{$\begin{array}{l}\text { Mean Global Happiness Score among the countries } \\
\text { of Masculine dominated Culture for three periods }\end{array}$} & $2010-12 \& 2012-14$ & $z=0.111$ & $1.96, \mathrm{n} 1=\mathrm{n} 2=37$ & $\mathrm{H}_{0}$ is accepted \\
\hline & & $2012-14$ \& 2014-16 & $z=-0.189$ & $1.96, \mathrm{n} 2=\mathrm{n} 3=37$ & $\mathrm{H}_{0}$ is accepted \\
\hline & & 2014-16to $2010-12$ & $z=0.309$ & $1.96, \mathrm{n} 3=\mathrm{n} 1=37$ & $\mathrm{H}_{0}$ is accepted \\
\hline \multirow[t]{3}{*}{16} & \multirow{3}{*}{$\begin{array}{l}\text { Mean Global Happiness Score among the countries } \\
\text { of Feminine dominated Culture for three periods }\end{array}$} & $2010-12 \& 2012-14$ & $t=0.07$ & 2.003, n1=n2=29 & $\mathrm{H}_{0}$ is accepted \\
\hline & & $2012-14$ \& 2014-16 & $t=0.225$ & $2.003, n 2=n 3=29$ & $\mathrm{H}_{0}$ is accepted \\
\hline & & 2014-16to 2010-12 & $t=0.289$ & $2.003, n 3=n 1=29$ & $\mathrm{H}_{0}$ is accepted \\
\hline 17 & $\begin{array}{l}\text { Mean Global Happiness Score between Masculine \& } \\
\text { Feminine cultured countries for three periods }\end{array}$ & $2010-12$ to $2014-16$ & $z=0.502$ & $1.96, \mathrm{n} 1=111 \mathrm{n} 2=87$ & $\mathrm{H}_{0}$ is accepted \\
\hline \multirow[t]{3}{*}{18} & \multirow{3}{*}{$\begin{array}{l}\text { Mean Global Happiness Score among the countries } \\
\text { of High UAI Culture for three periods }\end{array}$} & $2010-12 \& 2012-14$ & $z=0.126$ & $1.96, n 1=n 2=41$ & $\mathrm{H}_{0}$ is accepted \\
\hline & & $2012-14$ \& 2014-16 & $z=-0.249$ & $1.96, n 2=n 3=41$ & $\mathrm{H}_{0}$ is accepted \\
\hline & & 2014-16to 2010-12 & $z=0.383$ & 1.96, n3=n1=41 & $\mathrm{H}_{0}$ is accepted \\
\hline \multirow[t]{3}{*}{19} & \multirow{3}{*}{$\begin{array}{l}\text { Mean Global Happiness Score among the countries } \\
\text { of Low UAI Culture for three periods }\end{array}$} & $2010-12 \& 2012-14$ & $t=0.059$ & $2.011, \mathrm{n} 1=\mathrm{n} 2=25$ & $\mathrm{H}_{0}$ is accepted \\
\hline & & $2012-14 \& 2014-16$ & $t=0.198$ & $2.011, n 2=n 3=25$ & $\mathrm{H}_{0}$ is accepted \\
\hline & & 2014-16to 2010-12 & $t=0.255$ & $2.011, n 3=n 1=25$ & $\mathrm{H}_{0}$ is accepted \\
\hline 20 & $\begin{array}{l}\text { Mean Global Happiness Score between High UAI } \\
\text { and Low UAl cultured countries for three periods }\end{array}$ & $2010-12$ to $2014-16$ & $z=-2.158$ & $\begin{array}{l}Z \text { falls beyond } \pm 1.96 \text { range, } n 1=75 \\
n 2=123\end{array}$ & $\mathrm{H}_{0}$ is rejected \\
\hline \multirow[t]{3}{*}{21} & \multirow{3}{*}{$\begin{array}{l}\text { Mean Global Happiness Score among the countries } \\
\text { of LTO Culture for three periods }\end{array}$} & $2010-12 \& 2012-14$ & $t=0.084$ & $2.179, \mathrm{n} 1=\mathrm{n} 2=7$ & $\mathrm{H}_{0}$ is accepted \\
\hline & & $2012-14$ \& 2014-16 & $t=0.189$ & $2.179, \mathrm{n} 2=\mathrm{n} 3=7$ & $\mathrm{H}_{0}$ is accepted \\
\hline & & 2014-16to $2010-12$ & $\mathrm{t}=0.280$ & $2.179, \mathrm{n} 3=\mathrm{n} 1=7$ & $\mathrm{H}_{0}$ is accepted \\
\hline \multirow[t]{3}{*}{22} & \multirow{3}{*}{$\begin{array}{l}\text { Mean Global Happiness Score among the countries } \\
\text { of STO Culture for three periods }\end{array}$} & $2010-12 \& 2012-14$ & $t=0.007$ & $2.032, \mathrm{n} 1=\mathrm{n} 2=18$ & $\mathrm{H}_{0}$ is accepted \\
\hline & & $2012-14$ \& 2014-16 & $t=0.172$ & $2.032, n 2=n 3=18$ & $\mathrm{H}_{0}$ is accepted \\
\hline & & 2014-16to $2010-12$ & $t=0.177$ & $2.032, n 3=n 1=18$ & $\mathrm{H}_{0}$ is accepted \\
\hline 23 & $\begin{array}{l}\text { Mean Global Happiness Score between LTO and } \\
\text { STO cultured countries for three periods }\end{array}$ & $2010-12$ to $2014-16$ & $F=0.0416$ & $3.124, \mathrm{n} 1=21, \mathrm{n} 2=54$ & $\mathrm{H}_{0}$ is accepted \\
\hline
\end{tabular}

Table 3: Statistical results of the research study.

periods. But the mean score of happiness between HUAI and LUAI cultured countries do differ significantly for the selected time periods (Table 3, hypotheses No. 18, 19 and 20).

Countries with LTO culture disclosed same degree of happiness among the three periods of time. The countries with STO culture also disclosed the same level of happiness for the selected time periods. Further, it is found that there is no significant difference in the mean score of happiness between LTO and STO countries for the three time 
periods (Table 3, hypotheses No. 21, 22 and 23).

\section{Implications}

The following are the implications drawn based on the results of the research study:

- The mean score of happiness at the global level is just 5.4 out of 10 point scale, implying that humankind is able to draw $50 \%$ of happiness out of their life. Should we mean "the golden age" of history is just a dream for the present human race?

- Declining trend of mean scores (in absolute terms) of happiness at global level implying that there is increase of unhappiness on the part of humankind

- Periodical progress (from 2010-12 to 2014-16) in mean score of happiness is absent irrespective of countries, different continents and cultural differences on the whole.

- $45 \%$ of the nations (from Australia, North America, South America and Europe) only above the mean score of Global happiness. This implies that $55 \%$ of the nations of the world are below the average of global happiness. This implies further that majority of the human race on the planet is less than $50 \%$ happy.

- IDV cultured countries proved to be higher in scores of happiness when compared to that of Team oriented cultured countries. This implies that Team oriented cultured countries have to adopt the good practices of IDV cultured countries at professional level, organizational level and personal and domestic levels.

- LPDIcultured countries are happier than that of HPDI cultured countries. This implies that High Power Distance Cultured countries have to transform into LPDI culture in professional, organizational and personal and domestic levels to achieve the desired levels of happiness.

- Masculine dominated and feminine dominated countries are more or less equally happy implying that these cultures have no impact on the degree of happiness.

- HUAI cultured countries are happier than that of LUAI cultured countries. Therefore LUAI cultured countries are required to adopt the good practices to accomplish high score of happiness

- LTO and STO cultures have no impact on the degree of happiness. However medium term orientation is desired to adopt keeping the fact that future is uncertain.

\section{Suggestions}

The following are the strategies recommended for the improvement of happiness in the life of humankind.

\section{Balanced economic development}

The government of every country required to plan for the effective utilization of resources of the country for the economic empowerment of its people. Within the country there can be states and districts. A perfect bottom-up approach is desired to plan for the effective use of resources both natural and human skills from micro level to macro that is national perspective.
The efforts of the region heads like SAARC (South Asian Association for Regional Cooperation), South Asia Pacific Region, BRICS (BRAZIL, RUSSIA, INDIA, CHINA \& SOUTH AFRICA), UNESCO (United Nations Educational, Scientific and Cultural Organization), G-20 nations, IMF, WTO, World Bank etc are to be coordinated effectively in the respective nations and continents and the specific regions. If all the countries in a continent are well developed economically hence the continent's economic growth will also be significant. Economic development reduces unemployment and increases purchasing power and hence quality of human life and standard of living of the people will increase whereby happiness also will increase.

\section{Focus on non-economic activities}

The governments of the countries also have to make a visit to the countries of higher happiness and study what more factors, other than economic development, with which people are more happy such as quality education on parlance with the global standards, cost effective but sophisticated health care facilities, healthy entertainment and amusement services, safety; life security, family security, law and order to control crime rate etc and execute those things also for making the citizens happy.

\section{Gender diversity}

One of the findings of this research is that masculine dominated culture and feminine dominated culture do not have any impact on the degree of happiness. This is a welcoming feature. The masculine countries whose happiness is less than global average must come forward to promote gender diversity with which the country image will be enhanced and all types of supports can be sought from the well to do nations and global organizations.

\section{Future orientation and uncertainty avoidance schemes}

It is found that LTO and STO do not have significant impact on the degree of global happiness. But the number of countries falling under each category is less from the sample size perspective, however the governments of the nations should look forward to see that 20-30 percent of the earnings of all be saved in better yielding safe avenues for their future to avoid uncertainty of emergencies and exigencies.

Further the governments of the respective nations and regions for cooperation all should work and develop schemes to avoid uncertainty. The science and technology developed by a nation be accessible for all for the betterment of the citizens of the world.

\section{Transformation in the organizational culture}

The LPDI cultured countries by adopting flatter structure in their organizations, jeopardizing the distance among managerial staff, clerical staff and the workers, use of team-work and involving as many as possible in decision making can bring improvement in the degree of happiness of its people.

\section{Cultural diversity and cross cultural convergence}

The countries of low happiness should aim for cultural diversity by various collaborations namely, educational institutions collaborations in terms of student exchange, faculty exchange programs, research projects' collaborations, attracting inbound and outbound students, revising curriculum comparable to global standards, developing foreign collaborations for their business and manufacturing enterprises and focusing cross-cultural activities 
Citation: Dulababu T (2017) Global Happiness: Continental and Cross-Cultural Models Perspective. J Glob Econ 5: 268. doi: 10.4172/23754389.1000268

\section{Discussion and Conclusion}

The scope for future research topics are listed as follows:

- Global Happiness: Continental and Economic Perspective

- Global Happiness: Regional and Socio-economic Perspective

- Australian Vs. American Happiness: Cross-cultural Perspective.

\section{References}

1. Oswald A, Proto E, Sgroi D (2009) Happiness and Productivity. IZA Discussion Paper.

2. Veenhoven R (2008) Healthy Happiness: Effects of Happiness on Physical Health and the Consequences for Preventive Health Care. Journal of Happiness Studies 9: 449-469.

3. Luo L, Robin G (2004) Culture and Conceptions of Happiness: Individual Oriented and Social Oriented SWB. Journal of Happiness Studies 5: 269-291.

4. Diener E, Oishi S, Richard E, Lucas R (2003) Personality, culture, and subjective well-being: Emotional and cognitive evaluations of life. Annual Review of Psychology 5: 403-425.

5. Suh EM (2002) Culture, identity consistency, and subjective well-being. Journal of Personality and Social Psychology 83:1378-1391.
6. Lu L, Gilmour R, Kao SF (2001) Cultural values and happiness: An east-west dialogue. Journal of Social Psychology 141: 477-493.

7. Markus HR, Kitayama S (1991) Culture and the self: Implications for cognition emotion, and motivation. Psychological Review 98: 224-253.

8. Oyserman D, Coon HM, Kemmelmeier M (2002) Rethinking individualism and collectivism: Evaluation of theoretical assumptions and meta-analyses. Psychological Bulletin 128: 3-72.

9. Kitayama S, Mesquita B, Karasawa M (2006) Cultural affordances and emotional experience: Socially engaging and disengaging emotions in Japan and the United States. Journal of Personality and Social Psychology 91: 890-903.

10. Uchida Y, Kitayama S (2009) Happiness and unhappiness in east and west: Themes and variations. Emotion 9: 441-456.

11. Arrindell WA, Hatzichristou C, Wensink J, Rosenberg E, van Twillert B, et al (1997) Dimensions of national culture as predictors of cross-national differences in subjective well-being. Personality and Individual Differences, 23: 37-53.

12. Chui A, Kwok C (2008) National culture and life insurance consumption. Journal of International Business Studies 39: 88-101.

13. Javidan M, House RJ (2001) Cultural acumen for the global manager: Lessons from project GLOBE. Organizational Dynamics 29: 289-305.

14. House RJ, Hanges PJ, Javidan M, Dorfman PW, Gupta V (2004) Culture, leadership, and organizations: The GLOBE study of 62 societies. 